\section{UNIVERSITY \\ OF DEBRECEN}

FACULTY OF

HEALTH

NYÍREGYHÁZA

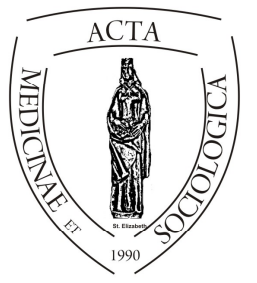

ACTA

MedSoc

VOLUME 5.

2014

\title{
A jövedelmi helyzet változása, a társadalmi polarizálódás jellemzői Nyíregyháza városában
}

\author{
Fábián Gergely - Takács Péter - Szigeti Fruzsina
}

\section{Debreceni Egyetem, Egészségügyi Kar}

\begin{abstract}
The effects of the socio-economic crisis in Nyíregyháza was the greatest between 2008 and 2010. Employment decreased and the number of the unemployed increased together with the proportion of people living in poverty. Overall, the decrease of income was very clearly shown in measurements taken during that time. The period between 2010 and 2012 was a time of economic recovery: the rate of the employment increased and so did the nominal values of income. This increase was measurable in both the total income per household and the income per capita. The rate of people living in poverty also showed a slight decrease.

Despite the positive trends, income inequality increased in the city, with the difference between the poor and the rich becoming larger, and income polarization greater.

In the most disadvantaged groups, income per capita became nominally smaller, and their share of the total measurable income decreased. For those in the lower third of the local society, employment decreased. This resulted in cumulative disadvantage, an unfavourable labour market situation, lower level of education, lack of vocational training, and low, continually decreasing income. Furthermore, households now had a larger number of members, that created a major and ever increasing burden for economic support.
\end{abstract}

Keywords: income inequality, poverty, polarization

DOI: $10.19055 / \mathrm{ams} .2014 .5 / 12-13 / 4$ 
Eddigi kutatási eredményeink alapján elmondható, hogy a városra jellemzö jövedelmi helyzet jellemzői, illetve annak változásai számos esetben „lekövették” az országos tendenciákat. Néhány kivétellel hasonló volt a helyzet 2012-ben is, bizonyos mérőszámok azonban eltértek az országos jellemzőktől.

A jövedelmek vizsgálatánál - a panelkutatások esetében - a háztartásokban keletkező nettó, szabadrendelkezésü jövedelmek jellemzőit és különböző eloszlásait elemezzük, nincsenek információk a bruttó jövedelmekről, illetve a bruttó és nettó jövedelmek ,viszonyáról”.

2012-ben a magyar háztartások egy före jutó nettó jövedelmének átlaga az összes személyre számítva 84 ezer forint volt, ami 13,5 százalékos nominális növekedést jelent 2009-hez képest, amikor is ez az összeg még 74 ezer forint körül alakult (TÁRKI, 2013). Hasonló nominális növekedés mérhető Nyíregyháza városában is, eltérés a növekedés mértékében $(8,7 \%)$, és az egy före jutó átlagjövedelem esetében mérhető, ami a városban alacsonyabb, mint országosan. Nyíregyházán 2010-ben 68 ezer forint egy före jutó átlagjövedelem volt mérhető, 2012-ben ez az összeg valamivel meghaladta a 74 ezer forintot, azaz az országosan 2009-re jellemző értéket.

Az átlagjövedelem növekedése mindenképpen pozitívan értékelhető fejlemény, különösen, ha azt is figyelembe vesszük, hogy 2008 és 2012 között egy hazánkat is érintő gazdasági, financiális válság időszakát éltük. ${ }^{1}$ A növekedés hátterében vélhetően a 2012-re már kedvezőbb foglalkoztatási helyzet állt, hiszen kutatásunkban arra a kérdésre, hogy „Dolgozik-e Ön jelenleg” a válaszadók 54,9 százaléka válaszolt igennel 2008-ban, 54,5\% 2010-ben és 57,2\% 2012-ben. ${ }^{2}$

A jövedelmek vizsgálatánál az átlagérték egy igen jól használható mutató, különösen az időbeli és térbeni összehasonlítások tekintetében, mégis „csalóka” lehet sok esetben, mivel elfed(het) olyan különbségeket, amelyek eröteljesen meghatározhatják a lakosok életminőségét. Ez a helyzet Nyíregyháza esetében is, ugyanis kutatásunk eredményei szerint mind 2010-ben, mind 2012-ben a

\footnotetext{
${ }^{1}$ A vidéki Magyarország, a ,járadékos ország” helyzetét, és a komplex gazdasági válság hatásait igen részletesen elemzi Bódi Ferenc 2011-es tanulmánya.

${ }^{2}$ Bár kutatásunk módszertanilag különbözik a KSH által végzett munkaerő felméréstől (ott a 15 -74, illetve 15 - 64 év közötti korosztályokra vetítve mérik a foglalkoztatottságot, a nyíregyházi kutatás mintájába pedig eleve a 18 éves, vagy annál idősebbek kerülhettek be) a foglalkoztatottságra vonatkozó arány mégis igen hasonló az országoshoz, hiszen a 15-64 éves korosztályok esetében mért foglalkoztatási ráta Magyarországon szintén 57,2 \% volt. Nyíregyháza nagyon kedvező helyzetét mutatja, hogy a városban mért ráta meghaladja az Észak-Alföldi régió és a megye értékeit. A régióban az arány 47,9 \% volt 2012-ben, szemben a 2008-as 49,9 százalékkal, Szabolcs-Szatmár-Bereg megyében pedig $47,1 \%$.
} 
városra jellemző átlagjövedelem alatt élt a lakosok 57 százaléka. ${ }^{3}$ Így látható, hogy az átlag nem „középen” van, ezért minden egyes alkalommal figyelembe kell venni a mediánjövedelmet, amely valódi középértéket mutat, azaz kétfelé osztja a lakosokat a jövedelem alapján. 2010-ben a medián értéke 62.500 forint, míg 2012-ben 66.666 forint volt. A medián értéke szerényebb mértékü (6.6 \%), de határozott növekedést mutat. Mivel 2012-re vonatkozóan az infláció mértéke $5,7 \%$ volt (KSH, 2013a), várható, hogy egyes társadalmi csoportok esetében a jövedelmek reálértékben csak enyhén növekedtek, illetve szinten maradtak.

A TÁRKI 2012-re vonatkozó adatai szerint a jövedelemeloszlás két szélén (legalacsonyabb jövedelmü tized, legmagasabb jövedelmü tized) az átlaghoz képest lényegesen eltérő tendenciák következtek be, azaz a jövedelmek növekedése differenciáltan ment végbe az utóbbi években. Ez a helyzet jellemzi a nyíregyháziakat is.

\begin{tabular}{|c|c|c|c|}
\hline & 2010 & 2012 & $\%$ \\
\hline Alsó decilis & 22,988 & 22,487 & $-2,1$ \\
\hline 2. Decilis & 36,751 & 38,359 & $+4,3$ \\
\hline 3. Decilis & 44,244 & 48,482 & $+9,6$ \\
\hline 4. Decilis & 50,025 & 56,787 & $+13,5$ \\
\hline 5. Decilis & 58,108 & 63,748 & $+9,7$ \\
\hline 6. Decilis & 66,486 & 72,450 & $+8,9$ \\
\hline 7. Decilis & 74,873 & 81,211 & $+8,4$ \\
\hline 8. Decilis & 85,297 & 95,185 & $+11,6$ \\
\hline 9. Decilis & 99,361 & 113,259 & $+14,0$ \\
\hline Felső decilis & 153,302 & 174,524 & $+12,0$ \\
\hline S10/S1 & 6,6 & 7,7 & \\
\hline
\end{tabular}

1. táblázat: A jövedelmek egyenlőtlenségei a városban - az egy före jutó háztartási jövedelmek eloszlása a jövedelmi tizedek szerint, 2010-2012. (Átlagértékek, forintban).

Forrás: saját adatfelvételek.

\footnotetext{
${ }^{3}$ Ez az adat arra utal, hogy a jövedelmek növekedése valószínűsíthetően csak egyes társadalmi csoportokra volt jellemző, azaz „nem terült szét” a lakosság körében.
} 
A legszegényebb 10 százalék esetében nominális csökkenés mérhető, ami megegyezik az országos trenddel. Az adat esetükben mélyülő szegényedésre utal. A második decilis esetében ugyan növekedés mérhető, ez azonban elmaradt az inflációtól, így ebben az esetben is további elszegényedési folyamatok feltételezhetőek. Ezzel szemben a két legtehetősebb csoport esetében az inflációt meghaladó mértékben nőttek a jövedelmek. A legalsó és a legfelső decilis közötti különbség 2010-ben 6,6-szeres volt, ezzel szemben 2012-ben már 7,7-szeres, ami egyértelmüen jelzi a jövedelmi egyenlőtlenségek növekedését. A 7,7 érték magasabb, mint 2008-ban, amikor is a mutató értéke 7,2 volt. A nyíregyházi adatokat érdemes összevetni az országos jellemzőkkel:

\begin{tabular}{|c|c|c|}
\hline Decilisek & Ország & Nyíregyháza \\
\hline 1. & 21,820 & 22,487 \\
\hline 2. & 38,042 & 38,359 \\
\hline 3. & 49,320 & 48,482 \\
\hline 4. & 60,154 & 56,787 \\
\hline 5. & 71,282 & 63,748 \\
\hline 6. & 80,588 & 72,450 \\
\hline 7. & 90,821 & 81,211 \\
\hline 8. & 103,856 & 95,185 \\
\hline 9. & 126,458 & 113,259 \\
\hline 10. & 196,625 & 174,524 \\
\hline$A T L A G$ & 83,885 & 74,458 \\
\hline$S 10 / S 1^{4}$ & 9,0 & 7,7 \\
\hline
\end{tabular}

2. táblázat: A jövedelmek egyenlőtlenségei - az egy före jutó háztartási jövedelmek eloszlása a jövedelmi tizedek szerint, 2012. (Átlagértékek, forintban).

Országos adatok: 2012 Forrás: TÁRKI, 2013.

Az egyes decilisek jövedelmi átlagai Nyíregyházán számos csoport esetében alacsonyabbak, mint országosan. Ez okozza azt, hogy az S10/S1 mutató országosan magasabb, vagyis országosan erőteljesebbek az egyenlőtlenségek. Ez a mutató országosan 7,2-ről nőtt 9-re, 2009 és 2012 között. Az egyenlőtlenségek növekedése így mind országosan, mind lokálisan kimutatható, igaz a városban valamivel kisebb értékek mérhetőek.

\footnotetext{
${ }^{4} \mathrm{~S} 10 / \mathrm{S} 1=\mathrm{A}$ legalsó decilis és a legfelső decilis átlagjövedelmének hányadosa.
} 
A jövedelmi egyenlőtlenségek növekedésére utalnak azok az adatok is, amelyek azt mutatják, hogyan részesednek az egyes társadalmi csoportok az összes jövedelemböl. ${ }^{5}$

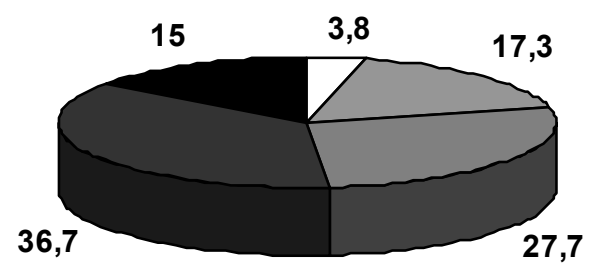

\begin{tabular}{|l|}
\hline $\begin{array}{l}\square z e g e ́ n y e k \quad \square \text { Alsó középréteg } \square \text { Középréteg } \\
\square \text { Felsö középréteg } \square \text { Jómódúak }\end{array}$ \\
\hline
\end{tabular}

1. ábra: Az egyes társadalmi csoportok részesedése az összjövedelemből, 2010 (\%). Forrás: saját adatfelvétel, 2010.

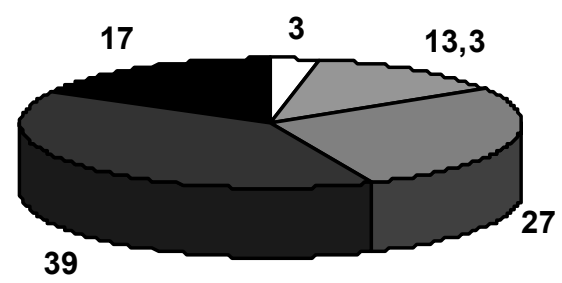

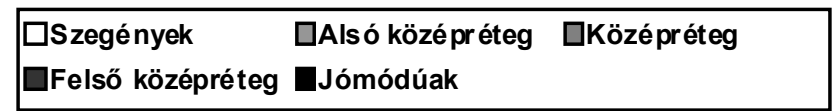

2. ábra: Az egyes társadalmi csoportok részesedése az összjövedelemből, 2012 (\%). Forrás: saját adatfelvétel, 2012.

\footnotetext{
5 Az egyes társadalmi csoportok besorolásánál a TÁRKI definícióit követtük, mely szerint: „Jómódúak” (akiknek a medián kétszeresénél több a jövedelme), „Felsöközépréteg” (a medián 120-200 \%-a), Középréteg” (a medián 80-120\%-a), „Alsó középréteg” (a medián 50-80\%-a), „Szegények” (50\% alatt).
} 
Azonosnak mondható helyzet kizárólag a középréteg esetében figyelhető meg, a szegények csoportjánál és az alsó középosztálynál csökkenés, míg a két legkedvezőbb helyzetü csoportnál növekedés mérhető. Másképp megfogalmazva mélyülő szegénységről, és bővülő gazdagságról beszélhetünk.

A jövedelmi egyenlőtlenségekre vonatkozó további mutatószámokat mutatjuk be az alábbi táblázatban:

\begin{tabular}{|c|c|c|c|}
\hline Mutatók $^{6}$ & $\begin{array}{c}\text { Nyíregyháza, } \\
2008\end{array}$ & $\begin{array}{c}\text { Nyíregyháza, } \\
2010\end{array}$ & $\begin{array}{c}\text { Nyíregyháza, } \\
2012\end{array}$ \\
\hline $\mathrm{p} 10 / \mathrm{p} 50$ & 0,51 & 0,48 & 0,48 \\
\hline $\mathrm{p} 90 / \mathrm{p} 50$ & 1,68 & 1,7 & 1,8 \\
\hline $\mathrm{p} 90 / \mathrm{p} 10$ & 3,30 & 3,55 & 3,75 \\
\hline $\mathrm{S} 10 / \mathrm{S} 1$ & 7,2 & 6,6 & 7,7 \\
\hline $\mathrm{S} 1$ & 3,1 & 3,8 & 3 \\
\hline S5+S6 & 17,2 & 18,6 & 15,3 \\
\hline S10 & 23,6 & 22,2 & 20,9 \\
\hline Robin Hood index & 20,0 & 20,0 & 20,0 \\
\hline Éltetó Frigyes index & 2,21 & 2,25 & 2,26 \\
\hline GINI & 0,285 & 0,290 & 0,290 \\
\hline
\end{tabular}

3. táblázat: A jövedelmi egyenlőtlenségek egyes mutatóinak változása a városban, 2008-2012.

Forrás: saját adatfelvételek.

Az egyenlőtlenségre vonatkozó mutatók arra utalnak, hogy a városban élő tehetősebb csoportok még tehetősebbek lettek (p90/p50; S10/S1; S5+S6, illetve különösen az Éltető Frigyes index). Ennek a folyamatnak nemcsak a jómódúak csoportja a nyertese, hanem sokkal inkább a felső középosztály. Erre utal az S10 és az S5+S6 mutató.

A városban 2008 és 2010 között folyamatosan nőtt a jómódúak aránya. Még dinamikusabban nőtt a felső középréteghez sorolhatók aránya, különösen 2010 után. ${ }^{7}$ A középréteg aránya 2008-hoz képest csökkent, egy nagyon enyhe növekedés mérhető 2010 után. Az alsó középréteg aránya különösen az elmúlt két évben csökkent. A szegénység 2008 és 2010 között nőtt, 2012-re enyhe csökkenést mutat, ugyanakkor még mindig magasabb, mint 2008-ban volt.

\footnotetext{
${ }^{6}$ A mutatók részletes magyarázatát a tanulmány végén található függelék tartalmazza.

${ }^{7}$ A 2008 és 2010 közötti időszak változásairól részletesen is írtunk a kutatás eredményeit bemutató kötetben: Fábián-Takács: A jövedelmi egyenlőtlenségek változásai és a szegénység. In: Fábián-Patyán-Huszti: Életminőség Nyíregyházán. Debreceni Egyetem Egészségügyi Kar, 2012. 33-49.
} 
Nyíregyházán tehát az elmúlt 4 évben az országoshoz hasonló tendenciák figyelhetők meg, bár a változások egyes esetekben más dinamikát követtek. A legszembetűnőbb eltérés, hogy míg 2010 és 2012 között országosan nőtt a jövedelmi szegények aránya, addig a városban ugyanebben az időszakban enyhe csökkenés figyelhető meg, amely minden számítás szerint 1 százalékos. ${ }^{8}$

\begin{tabular}{|c|c|c|}
\hline & 2010 & 2012 \\
\hline Egy före jutó jövedelem átlaga alapján & 14 & 13 \\
\hline $\begin{array}{c}\text { OECD2 skála* } \\
\text { (OECD1 skála)** }\end{array}$ & 16,6 & 15,5 \\
\hline Mediánjövedelem $50 \%$ & $(17,5)$ & $(14,4)$ \\
\hline
\end{tabular}

4. táblázat: A szegénységre vonatkozó mutatók, 2010-2012.

Forrás: saját adatfelvételek.

*A szegénységi küszöb az OECD2 skála alapján számolva a mediánjövedelem 60 \%-a. (Skála: felnőtt 1 , további felnőtt 0.5 , gyermek 0.3 súlyú fogyasztási egység)

**A szegénységi küszöb az OECD1 skála alapján számolva a mediánjövedelem 60 \%-a. (Skála: felnőtt 1 , további felnőtt 0.7 , gyermek 0.5 súlyú fogyasztási egység)

Amennyiben az egyes számításokat megpróbáljuk „egységesen értelmezni”, a városra egy 14 százalékos szegénységi ráta volt jellemző 2012-re, ami megegyezik az EU-SILC által Magyarországra közölt adatokkal (KSH, 2013b), ugyanakkor alacsonyabb értéket mutat a TÁRKI által mért 17 százalékos aránynál. ${ }^{9}$

Az országos tendenciákkal ellentétesen a városban így nem feltétlenül a szegénységben élők számának és arányának a növekedése okoz gondot (azzal a megjegyzéssel, hogy az arányok 2012-ben magasabbak voltak, mint 2008-ban), hanem sokkal inkább a szegények és gazdagok közötti jövedelmi olló nyílása,

\footnotetext{
${ }^{8}$ Ennek hátterében vélhetően a városnak a régióhoz képest sokkal kedvezőbb adatai állnak, pl. a foglalkoztatottság növekedése, illetve ezzel párhuzamosan, részben következményeként a háztartási, és az egy före jutó jövedelmek növekedése.

${ }^{9}$ Az eltérés oka, hogy a jövedelmi szegénység mérésénél használatos mutatók természetszerüleg erőteljesen korrelálnak a jövedelmi egyenlőtlenségek mutatószámaival, azaz sokkal inkább tekinthetők egyenlőtlenségi mutatóknak, mint a nélkülözés, a depriváció jellemzőinek, ahogyan erre Bruder Emese is utalt a közelmúltban megjelent tanulmányában (Bruder, 2014). Ez alapján mivel országosan eröteljesebbek a jövedelmi különbségek (pl a legalsó és a legfelső deciliseknél mért átlagjövedelem alapján), mint a városban, az ily módon mért szegénységi arány is eltérő, azaz a városban alacsonyabb, mint országosan.
} 
vagyis a szegények további elszegényedése, és a tehetősebbek további gazdagodása, azaz a jövedelmi polarizáció erősödése.

Kiemelésre érdemes, hogy a kedvezőtlenebb helyzetű csoportok esetében nagyobb méretü háztartásokkal kell számolni, vagyis ezekben a háztartásokban nagyobb az eltartási teher is. Bár, 2008-hoz képest csökkent a városi háztartások mérete, az összefüggés még ettől fennáll.

\begin{tabular}{|l|c|c|c|}
\hline & $\begin{array}{c}\text { Háztartás átlagos } \\
\text { létszáma, 2008 }\end{array}$ & $\begin{array}{c}\text { Háztartás átlagos } \\
\text { létszáma, 2010 }\end{array}$ & $\begin{array}{c}\text { Háztartások átlagos } \\
\text { létszáma, 2012 }\end{array}$ \\
\hline Szegények & 4,03 & 4,03 & 3,66 \\
\hline $\begin{array}{l}\text { Alsó középré- } \\
\text { teg }\end{array}$ & 3,43 & 3,51 & 3,48 \\
\hline Középréteg & 2,73 & 2,90 & 2,59 \\
\hline $\begin{array}{l}\text { Alsó középré- } \\
\text { teg }\end{array}$ & 2,15 & 2,30 & 2,10 \\
\hline Jómódúak & 1,84 & 1,89 & 1,85 \\
\hline
\end{tabular}

5. táblázat: A háztartások átlagos létszáma az egyes társadalmi csoportokban, 2008-2012 (átlagértékek, fó).

Forrás: saját adatfelvételek.

Ezt erősíti meg az az eredmény is, ha a szegénységet háztartástípusonként vizsgáljuk.

\begin{tabular}{|c|c|c|}
\hline Háztartástípus & 2010 & 2012 \\
\hline 1 aktív korú felnőtt & 10,3 & 8,0 \\
\hline 1 felnőtt 1 gyerek & 9,1 & 23,8 \\
\hline 1 felnőtt 2 gyerek & 26,7 & 61,5 \\
\hline 2 aktív korú felnött & 8,4 & 10,9 \\
\hline 2 felnőtt 1 gyerek & 12,5 & 12,1 \\
\hline 2 felnőtt 2 gyerek & 18,3 & 23,6 \\
\hline 2 felnőtt 3 gyerek & 22,2 & 31,8 \\
\hline
\end{tabular}

6. táblázat: Szegénységi ráták az egyes háztartástípusokban, 2010-2012 (\%). Forrás: saját adatfelvételek.

A szegénység kockázata elsősorban a többgyermekes, illetve a gyermekét, gyermekeit egyedül nevelők esetében jelentős.

A nagyobb eltartási teher egyéb hátrányos jellemzőkkel társul. A szegénységben élők csoportjában 52,3 \% nem rendelkezik munkával, közel $22 \%$ pedig csak 8 általánost végzett, ami kifejezetten hátrány a munkaeröpiacon. 
Bár a város esetében nem igazán szignifikáns az összefüggés, az életkor növekedésével csökken a szegénység kockázata, a fiatalabb korosztályok esetében magasabb rátákkal találkozhatunk, mint az időseknél. ${ }^{10}$

Érdekes kérdés, hogy az általunk vizsgált jellemzők hogyan és milyen mértékben befolyásolják a nyíregyházi lakosok életminőségét. Az életminőséget kutatási programunk 2010-es, második hullámában kidolgozott ún. FTI-index alkalmazásával mértük. ${ }^{11}$

\begin{tabular}{|c|c|c|c|}
\hline & 2008 & 2010 & 2012 \\
\hline Átlag & 6,0 & 5,7 & 6,3 \\
\hline Sztenderdizált szórás & 4,5 & 4,2 & 4,4 \\
\hline Minimum érték & $-6,5$ & $-10,8$ & $-6,0$ \\
\hline Maximum érték & 21,1 & 18,7 & 19,2 \\
\hline
\end{tabular}

7. táblázat: Az FTI alapértékei a városban, 2008-2012.

Forrás: saját adatfelvételek.

$\mathrm{Az}$ index egyes értékeinek változásai (pl. a minimum érték csökkenése, a maximum növekedése) mindenképpen kedvezőnek mondható. Következő lépésként azt vizsgáltuk, hogy a tanulmányunk szempontjából vizsgált legfontosabb jellemzők (jövedelem, iskolázottság, foglalkoztatottság, stb.) hogyan alakítják a kutatás két utolsó hullámában az FTI értékeit. ${ }^{12}$ Az első modellbe négy változót vontunk be (foglalkoztatottság, iskolai végzettség, az egy főre jutó jövedelem, a háztartások nagysága), ennek eredményeképpen a legerőteljesebben befolyásoló két tényező a foglalkoztatottság és az iskolai végzettség lett, ezt követően lépett be a modellbe a jövedelem és a háztartás nagysága. Ez az eredmény azonos volt mindkét vizsgálati évben, ami arra utal, hogy a háztartások tagjainak munkaeröpiaci helyzete gyakorolja a legerőteljesebb hatást az életminőségre. Természetesen ez a helyzet szoros összefüggést mutat a jövedelemmel és az iskolázottsággal, vagyis amennyiben valaki rendelkezik munkával és munkajövedelemmel, az eltartási teher is kisebb, hiszen a modellbe utolsóként lépett be a háztartás nagyságára vonatkozó változó.

\footnotetext{
${ }^{10}$ Ezt az összefüggést, illetve az idős korosztály jövedelmi helyzetét elemzi részletesen Patyán László 2012-es tanulmánya, kutatási programunk első tanulmánykötetében.

${ }^{11}$ Az index kialakításának módszertani leírását tartalmazza az „Életminőség Nyíregyházán" címü kötetben 2012-ben megjelent írásunk. Az FTI az életminőség 7 dimenzióját süríti egy mutatóba, melyek a következők: családi, baráti viszonyok, egészségi állapot, munka és aktivitás, anyagi jólét, a lokális közösséghez való tartozás, a környezet minősége és a személyes biztonság.

${ }^{12} \mathrm{Az}$ elemzést lépcsőzetes regresszió analízissel végeztük.
} 
Amennyiben a modellbe újabb változókat vonunk be, pl. az egészségi állapotra vonatkozó mutatókat, a krónikus betegségek jellemzőit, életkort, stb., a modell részben változik. Az első és a legerőteljesebben ható változó az egészségi állapot, ezt követően a már megismert sorrend látható. ${ }^{13}$

Mivel elemzésünk szempontjából a foglalkoztatottság minősült a legerősebb változónak, megvizsgáltuk, hogyan alakult a városban az egyes társadalmijövedelmi csoportok munkaerő-piaci helyzete, különösen annak ismeretében, hogy az adott időszakban mind az országos, mind a helyi adatok növekedést mutattak.

\begin{tabular}{|c|c|c|}
\hline Iskolai végzettség & 2010 & 2012 \\
\hline 8 általános, vagy alatta & 34,0 & 28,1 \\
\hline Szakmunkásképző & 61,1 & 63,8 \\
\hline Szakközépiskola & 67,9 & 73,6 \\
\hline Gimnázium & 62,6 & 70,2 \\
\hline Főiskola & 78,6 & 79,8 \\
\hline Egyetem & 84,0 & 82,9 \\
\hline Összesen & 54,2 & 57,1 \\
\hline
\end{tabular}

8. táblázat: A foglalkoztatottság alakulása a városban az iskolázottság függvényében, 2010-2012. (18-64 év között, \%). Forrás: saját adatfelvételek.

Alapvetően a középfokú végzettséggel, illetve a főiskolai diplomával rendelkezők körében nőtt a foglalkoztatottság, a legalacsonyabb végzettségüeknél azonban csökkent. ${ }^{14}$

\footnotetext{
${ }^{13}$ Ez az eredmény részben megerősíti az index logikai összetételét, illetve azt a feltételezést, hogy az életminőség összetett jellemző, nem mérhető kizárólag szociális és/vagy egészségügyi faktorokkal. Érdekes eredmény, hogy az elemzésnél mindkét év esetében a modell „kidobta” az életkori változót. Az egészségi állapot erőteljes hatása szinte természetes, hiszen meghatározója többek között a munkaképességnek is.

${ }^{14}$ Feltétlenül ki kell emelni, hogy az aktív korú városlakók körében folyamatosan csökken a 8 általánost végzettek aránya, foglalkoztatottságuk azonban mindenképpen kritikus. Az egyetemi diplomások körében mért egy százalékpontos csökkenést a rendelkezésünkre álló adatok alapján egyelőre nem tudjuk magyarázni.
} 


\begin{tabular}{|c|c|c|}
\hline & 2010 & 2012 \\
\hline Alsó decilis & 44,6 & 50,0 \\
\hline 2. decilis & 61,2 & 60,8 \\
\hline 3. decilis & 71,4 & 66,0 \\
\hline 4. decilis & 70,6 & 65,2 \\
\hline 5. decilis & 61,2 & 76,7 \\
\hline 6. decilis & 67,6 & 77,6 \\
\hline 7. decilis & 66,7 & 66,1 \\
\hline 8. decilis & 67,2 & 71,3 \\
\hline 9. decilis & 81,0 & 80,0 \\
\hline Legfelsö decilis & 78,5 & 84,7 \\
\hline Összesen & 54,2 & 57,1 \\
\hline
\end{tabular}

9. táblázat: A foglalkoztatottság alakulása az egyes jövedelmi tizedek függvényében, 2010-2012. (18-64 év között, \%).

Forrás: saját adatfelvételek.

Bár a legalsó decilis esetében enyhe növekedés mérhető, ez a kedvezőnek mondható emelkedés nem befolyásolta jövedelmi helyzetüket, hiszen ez az a jövedelmi tized, ahol 2010 és 2012 között nominális csökkenés volt mérhető. Az adatok jól tükrözik, hogy a város társadalmának legalsó harmada (2-4. decilis) esetében csökkent a foglalkoztatottak aránya, növekedés a felsőbb tizedek esetében jellemző.

\section{Összefoglalás - helyzetkép öt év és három adatfelvételi hullám távlatából}

A gazdasági-társadalmi válság hatásai 2008 és 2010 között voltak a legeröteljesebbek a városban, csökkent a foglalkoztatottság, nőtt a munkanélküliek száma, és nőtt a szegénységben élők aránya is. Általánosságban is jól mérhető volt a jövedelmek csökkenése ebben az időszakban. 2008 és 2010 között jelentősen romlottak az általunk kidolgozott életminőség index értékei is.

A 2010 és 2012 közötti periódus a válságból való kilábalás időszaka volt, nőtt a foglalkoztatottak aránya, nominális értékben is nőttek a jövedelmek (a növekedés mind a háztartásokra jutó összjövedelem, mind az egy före jutó jövedelmek esetében mérhető volt), a szegénységben élök aránya is enyhe csökkenést mutatott, és az FTI értékei is kedvezőbbek lettek. 
A kedvező tendenciák ellenére a városban nőttek a jövedelmi egyenlőtlenségek, nagyobb lett a szegények és a gazdagok közötti különbség, azaz erőteljesebb lett a jövedelmi polarizáció.

A legkedvezőtlenebb helyzetü csoportok esetében nominálisan is kisebb lett az egy főre jutó jövedelem, csökkent az összes mérhető jövedelemből való részesedésük. A helyi társadalom alsó harmadához tartozó decilisek esetében pedig csökkent a foglalkoztatottság. Esetükben kumulált hátrányokról beszélhetünk, kedvezőtlen munkaerő-piaci helyzetről, alacsony iskolázottságról, a szakképzettség hiányáról, alacsony és részben csökkenő jövedelemről, nagy létszámú háztartásokról, amely jelentős eltartási terheket is jelent. Amennyiben lokális életminőségről és lokális szociálpolitikáról beszélünk, a városban elsődleges feladatnak tünik ennek a jól körülhatárolható, többszörösen rászoruló társadalmi csoportnak a segítése.

\section{Felhasznált irodalom}

1. Bódi Ferenc (2011): A komplex válság elemei és hatása a vidéki társadalmakra. In: Bódi Ferenc-Fábián Gergely (szerk): Helyi szociális ellátórendszer Magyarországon. Debrecen University Press, Debrecen. 113-127.

2. Bruder Emese (2014): Kik a szegények Európában? A szegénység mérésének alternatívája. Területi Statisztika. 54/2. 152-171.

3. Fónai Mihály (2011): A települési problémák és a lakossági szükségletek lehetséges hatása a helyi politikára. In: Bódi Ferenc - Fábián Gergely (szerk): Helyi szociális ellátórendszer Magyarországon. Debrecen University Press, Debrecen. 127.

4. KSH (2013a): A fogyasztói árak alakulása 2012-ben. Budapest.

5. KSH (2013b): A relatív jövedelmi szegénység és a társadalmi kirekesztődés (Laeken-i indikátorok), 2012. Budapest.

6. Patyán László (2012): Időskorúak életminősége, 2010. In: Fábián Gergely Patyán László - Huszti Éva (szerk): Életminőség Nyíregyházán, 2008-2010. Debreceni Egyetem Egészségügyi Kar, Nyíregyháza. 117-134..

7. Takács Péter - Fábián Gergely (2012): Egy lokális életminőség index kialakításának lépései. In: Fábián Gergely - Patyán László - Huszti Éva (szerk): Életminőség Nyíregyházán, 2008-2010. Debreceni Egyetem Egészségügyi Kar, Nyíregyháza. 49-69.

8. TÁRKI (2013): Egyenlötlenség és polarizálódás a magyar társadalomban. Szerk.: Szívós Péter - Tóth István György. Budapest. 


\section{Melléklet}

A jövedelmi egyenlőtlenségekre vonatkozó mutatók:

$\mathbf{p 1 0 / p 5 0}=$ a mutatószám az alsó jövedelmi tized felső határpontját viszonyítja a mediánhoz.

$\mathbf{p 9 0 / p 5 0}=$ a mutatószám a legfelső jövedelmi tized alsó határát viszonyítja a mediánhoz.

p90/p10 = a mutatószám az alsó jövedelmi tized felső határpontját viszonyítja a felső jövedelmi tized alsó határpontjához.

$\mathbf{S 1 0} / \mathbf{S 1}=$ a legalsó decilis és a legfelső decilis átlagjövedelmének hányadosa, azaz hányszorosa a legfelső decilis átlagjövedelme a legalsónak.

$\mathbf{S 1}=$ a legalsó decilis részesedése az összes jövedelemből, százalékban.

$\mathbf{S 5 + S 6 = ~ a ~ k o ̈ z e ́ p e n ~ l e ́ v o ̋ ~ d e c i l i s e k ~ r e ́ s z e s e d e ́ s e ~ a z ~ o ̈ s s z e s ~ j o ̈ v e d e l e m b o ̋ l , ~ s z a ́ z a l e ́ k - ~}$ ban.

$\mathbf{S 1 0}=$ a legfelső decilis részesedése az összes jövedelemből, százalékban.

Robin Hood index $=$ az egyenlőtlenségek általános szintjének kimutatására szolgál. Kiindulópontja, hogy teljes egyenlöség esetén a jövedelmek egyenletesen oszlanak meg az egyének között, azaz mindegyik jövedelmi tizedbe a népesség összjövedelmének 10-10 százaléka esik. A Robin Hood-index ettől az egyenletes megoszlástól való eltérést mutatja: a 10 százaléknál nagyobb jövedelemaránnyal rendelkező decilisek 10 százalék feletti százalékrészeinek összegeként számolható ki. Másként megfogalmazva, ha akadna egy Robin Hood, aki a gazdagoktól elvett javakat a szegények számára szeretné újraosztani, akkor a szóban forgó index azt jelentené, hogy maximum mekkora hányadot kellene átcsoportosítani, hogy kiegyenlítődjenek a jövedelmi egyenlőtlenségek.

ÉItető Frigyes index: az átlag feletti és az átlag alatti jövedelmek hányadosa, azaz az átlag fölötti jövedelmek átlagát az átlag alatti jövedelmek átlagával vetjük össze. Teljes jövedelemegyenlőség esetén a mutató értéke 1, ennél nagyobb érték a jövedelmi olló nagyságát mutatja.

GINI= az egyenlőtlenség olyan mértékegysége, amely 0 és 1 között vehet fel értékeket. $0=$ teljes egyenlőség, $1=$ teljes egyenlőtlenség, azaz egy ember rendelkezik az összes jövedelemmel. A Gini-index azt méri, hogy egy adott országban, településen, stb. a jövedelmek eloszlása mennyiben tér el az abszolút egyenlőségtől. 
Fábián Gergely: föiskolai tanár

Debreceni Egyetem Egészségügyi Kar, 4400 Nyíregyháza, Sóstói u. 2-4.

Takács Péter: főiskolai docens

Debreceni Egyetem Egészségügyi Kar, 4400 Nyíregyháza, Sóstói u. 2-4.

Szigeti Fruzsina

Debreceni Egyetem Egészségügyi Kar, 4400 Nyíregyháza, Sóstói u. 2-4. 